\title{
Translational implication of Kallmann syndrome-1 gene expression in hepatocellular carcinoma
}

\author{
YURI TANAKA $^{1}$, MITSURO KANDA ${ }^{1}$, HIROYUKI SUGIMOTO ${ }^{1}$, DAI SHIMIZU ${ }^{1}$, \\ SATOSHI SUEOKA ${ }^{1}$, HIDEKI TAKAMI ${ }^{1}$, KAZUHIRO EZAKA ${ }^{1}$, RYOJI HASHIMOTO ${ }^{1}$, \\ YUKIYASU OKAMURA ${ }^{2}$, NAOKI IWATA ${ }^{1}$, CHIE TANAKA ${ }^{1}$, SUGURU YAMADA ${ }^{1}$, \\ TSUTOMU FUJII $^{1}$, GORO NAKAYAMA ${ }^{1}$, MASAHIKO KOIKE ${ }^{1}$, SHUJI NOMOTO ${ }^{3}$, \\ MICHITAKA FUJIWARA $^{1}$ and YASUHIRO KODERA ${ }^{1}$ \\ ${ }^{1}$ Department of Gastroenterological Surgery (Surgery II), Nagoya University Graduate School \\ of Medicine, Nagoya 466-8550; ${ }^{2}$ Department of Hepato-Biliary-Pancreatic Surgery, \\ Shizuoka Cancer Center, Shunto, Shizuoka 411-8777; ${ }^{3}$ Department of Surgery, \\ Aichi-Gakuin University School of Dentistry, Chikusa-ku, Nagoya 464-8651, Japan
}

Received February 19, 2015; Accepted March 26, 2015

DOI: 10.3892/ijo.2015.2965

\begin{abstract}
Accumulation of epigenetic alterations causes inactivation of tumor suppressors and contributes to the initiation and progression of hepatocellular carcinoma (HCC). Identification of methylated genes is necessary to improve our understanding of the pathogenesis of HCC and develop novel biomarkers and therapeutic targets. The Kallmann syndrome-1 (KAL1) gene encodes an extracellular matrixrelated protein with diverse oncological functions. However, the function of KAL1 in HCC has not been examined. We investigated the methylation status of the KAL1 promoter region in HCC cell lines, and evaluated KAL1 mRNA levels and those of genes encoding potential interacting cell adhesion factors. KAL1 mRNA expression level was heterogeneous in nine HCC cell lines, and reactivation of KAL1 mRNA expression was observed in cells with promoter hypermethylation of KAL1 gene after demethylation. In addition, KAL1 mRNA levels inversely correlated with those of ezrin in all nine HCC cell lines. KAL1 expression levels in 144 pairs of surgically-resected tissues were determined and correlated to clinicopathological parameters. KAL1 mRNA level was independent of the background liver status, whereas HCC tissues showed significantly lower KAL1 mRNA levels than corresponding noncancerous liver tissues. Downregulation of KAL1 mRNA in HCC was significantly associated with
\end{abstract}

Correspondence to: Dr Mitsuro Kanda, Department of Gastroenterological Surgery (Surgery II), Nagoya University Graduate School of Medicine, 65 Tsurumai-cho, Showa-ku, Nagoya 466-8550, Japan E-mail:m-kanda@med.nagoya-u.ac.jp

Key words: hepatocellular carcinoma, Kallmann syndrome-1, methylation, tumor suppressor, biomarker malignant phenotype characteristics, including elevated tumor markers, larger tumor size, vascular invasion, and hypermethylation of KAL1. Patients with downregulation of KAL1 were more likely to have a shorter overall survival than other patients, and multivariate analysis identified downregulation of KAL1 as an independent prognostic factor (hazard ratio $2.04,95 \%$ confidence interval 1.11-3.90, $\mathrm{P}=0.022$ ). Our results indicated that KAL1 may act as a putative tumor suppressor in $\mathrm{HCC}$ and is inactivated by promoter hypermethylation. KAL1 may serve as a biomarker of malignant phenotype of HCC.

\section{Introduction}

Hepatocellular carcinoma (HCC) is the most common primary malignancy of the liver and the third most common cause of cancer-related death worldwide $(1,2)$. Development of HCC is considered as a discriminative event because it occurs in chronically damaged tissue due to chronic hepatitis and liver cirrhosis, whereas other common malignancies develop on otherwise healthy tissue (3-5). Because of the accumulated genome instability and numerous epigenetic alterations induced by the microenvironment of the background liver, $\mathrm{HCC}$ is a more heterogeneous disease (3).

Aberrant DNA methylation is one of the most common epigenetic alterations in malignancies and is specific to individual organs and diseases (6-8). Furthermore, several studies have shown that aberrant DNA methylation contributes to the initiation and progression of malignant tumors through inactivation of tumor suppressors $(9,10)$. Therefore, identification of novel methylated genes is important for the development of both diagnostic markers and therapeutic targets, such as demethylation agents.

Kallmann syndrome-1 gene (KAL1), also named anosmin-1, encodes an extracellular matrix (ECM) related protein with a role in cellular adhesion. KAL1 contains a WAP domain and three FnIII domains, and promotes the migration of gonadotropin-releasing hormone neurons from the olfactory 
placode to the hypothalamus during development (11-13). KAL1 also induces neurite outgrowth and cell migration through fibroblast growth factor receptor 1 (FGFR1) pathways $(14,15)$. Studies have demonstrated that ECM proteins play a vital role in proliferation and invasion of tumor cells (16). However, to date, conflicting results have been reported regarding the oncological role of KAL1. Decreased KAL1 expression is observed in colon, lung, and ovarian cancers compared with corresponding adjacent normal tissues (17). Conversely, KAL1 overexpression promotes brain tumor malignancy through integrin signal pathways and facilitates colon cancer cell migration and antiapoptotic capacity (15). These studies indicate that KAL1 exhibits diverse functions in cancer initiation and progression. To the best of our knowledge, there have been no studies of expression analysis of KAL1 in HCC. Moreover, although lossof-function mutations of the KAL1 gene have been known to underlie Kallmann syndrome $(18,19)$, the significance of the methylation status of the KAL1 gene has yet to be determined.

In our previous microarray project exploring HCC-related tumor suppressors, we found that KAL1 was downregulated in HCC tissues (Log2 ratio: -2.1) (16,20-22). Accordingly, we hypothesized that KAL1 might act as a putative tumor suppressor and mediate tumorigenesis of HCC. To systematically address this idea, we examined the expression and methylation status of KAL1 in HCC.

\section{Materials and methods}

Sample collection. We purchased nine HCC cell lines from the American Type Culture Collection (Manassas, VA, USA) and cultured cells as previously described (23). Primary HCC and adjacent liver tissues were collected from 144 patients who underwent hepatectomy for HCC at Nagoya University Hospital between January 1998 and January 2012. The ages of the 144 patients ranged from 34 to 84 years (median, 65.5 years), and the male-to-female ratio was 121:23. The median duration of patient follow-up was 40.1 months (range, 2.3-145 months). Thirty-seven were infected with hepatitis $\mathrm{B}$ and 80 patients were infected with hepatitis $\mathrm{C}$ virus. Ten patients had normal liver, 82 patients had chronic hepatitis, and 52 patients showed cirrhosis. Ninety, 37, and 17 patients were in stages I, II, and III, respectively.

Tissue samples were frozen immediately after resection and stored at $-80^{\circ} \mathrm{C}$ until use. Genomic DNA and total RNA was extracted from both HCC and adjacent noncancerous tissues approximately $5 \mathrm{~mm}^{2}$ in diameter, avoiding necrotic areas. Specimens were classified histologically according to the 7th edition of the Union for International Cancer Control (24). Written informed consent for the use of clinical samples and data was obtained from all enrolled patients as required by the Institutional Review Board of Nagoya University, Japan.

Analysis of the KAL1 promoter region. Nucleotide sequencing was used to determine the presence of $\mathrm{CpG}$ islands in the KAL1 promoter region, defined as follows: $\geq 200$ bp region with GC content $>50 \%$ and an observed $\mathrm{CpG} /$ expected $\mathrm{CpG}$ ratio $\geq 0.6$ (25). CpG Island Searcher software (http://cpgislands.usc.edu/) was used to determine the locations of $\mathrm{CpG}$ islands (26).
Quantitative real-time reverse transcription-polymerase chain reaction $(q R T-P C R)$. KAL1 mRNA levels were determined using qRT-PCR. Total RNA $(10 \mu \mathrm{g})$ was isolated from nine HCC cell lines, 144 primary HCCs, and adjacent noncancerous tissues and used as a template for complementary DNA synthesis. Glyceraldehyde-3-phosphate dehydrogenase (GAPDH) mRNA (TaqMan, GAPDH control reagents, Applied Biosystems, Foster City, CA, USA) was quantified in each sample for standardization. Specific primers and annealing temperatures are listed in Table I. qRT-PCR was performed using the SYBR Green PCR Core Reagents kit (Applied Biosystems) as follows: one cycle at $95^{\circ} \mathrm{C}$ for $10 \mathrm{~min}, 40$ cycles at $95^{\circ} \mathrm{C}$ for $5 \mathrm{sec}$, and $60^{\circ} \mathrm{C}$ for $60 \mathrm{sec}$. Real-time detection of SYBR Green fluorescence was conducted using an ABI StepOnePlus Real-Time PCR System (Applied Biosystems). All samples were analyzed in triplicate. The expression level of each sample is shown as the value of the KAL1 amplicon divided by that of GAPDH (27).

Methylation-specific PCR (MSP) and bisulfite sequence analysis. Genomic DNA samples from nine HCC cell lines and 144 HCC tissues were subjected to bisulfite treatment. MSP was conducted to determine the presence or absence of promoter hypermethylation of KAL1 gene. Bisulfite DNA from HCC cell lines was sequenced to determine the reliability of MSP results. Primer sequences are shown in Table I.

5-Aza-2'-deoxycytidine (5-aza-dC) treatment. To assess the relation of promoter hypermethylation to KAL1 transcription, HCC cell lines were treated with the DNA methylation inhibitor 5-aza-dC (Sigma-Aldrich, St. Louis, MO, USA) as previously described $(10,28)$.

Expression of genes that encode cell adhesion factors. To identify cell adhesion proteins that may interact with KAL1, expression levels of Ezrin (EZR), focal adhesion kinase (FAK), cellular SRC (SRC) and dihydropyrimidinase-like 3 (DPYSL3) genes were determined by qRT-PCR in HCC cell lines $(29,30)$. Primers specific for EZR, FAK, SRC and DPYSL3 are listed in Table I.

Immunohistochemical (IHC) staining. KAL1 protein localization was determined by IHC using 64 representative formalin-fixed and paraffin-embedded sections of wellpreserved HCC tissue using a rabbit polyclonal antibody against KAL1 (ABN486, Millipore, Darmstadt, Germany) diluted 1:150 in antibody diluent (Dako, Glostrup, Denmark) as previously described $(7,31)$. Samples were then washed with phosphate-buffered saline, followed by $10 \mathrm{~min}$ incubation with a biotinylated secondary antibody (Histofine SAB-PO(R), Nichirei, Tokyo, Japan). Sections were subsequently developed for 3 min using 3,3'-diaminobenzidine as substrate (Nichirei) and analyzed. To avoid bias, specimens were randomized, coded, and then analyzed by two independent observers who were uninformed of the identities of the samples.

Statistical analysis. The qualitative $\chi^{2}$ test and quantitative Mann-Whitney test were used to compare two groups. Correlations between mRNA levels of KAL1 and those of EZR, 
Table I. Primers and annealing temperatures.

\begin{tabular}{|c|c|c|c|c|c|}
\hline Gene & Experiment & Type & Sequence $\left(5^{\prime}-3^{\prime}\right)$ & $\begin{array}{l}\text { Product size } \\
\qquad(\mathrm{bp})\end{array}$ & $\begin{array}{l}\text { Annealing } \\
\text { temperature }\left({ }^{\circ} \mathrm{C}\right)\end{array}$ \\
\hline \multirow[t]{4}{*}{$K A L 1$} & qRT-PCR & $\begin{array}{l}\text { Forward } \\
\text { Reverse }\end{array}$ & $\begin{array}{l}\text { AACAATGGTTCCCTGGTTTG } \\
\text { TCACAAAAGCTTTGGCACTG }\end{array}$ & 110 & 60 \\
\hline & MSP & $\begin{array}{l}\text { Forward } \\
\text { Reverse }\end{array}$ & $\begin{array}{l}\text { GTGCGAACGGGAGAGGC } \\
\text { GTCAACTACGAACCCGAACG }\end{array}$ & 109 & 68 \\
\hline & U-MSP & $\begin{array}{l}\text { Forward } \\
\text { Reverse }\end{array}$ & $\begin{array}{l}\text { AAAACCCATAAACCAATCTCA } \\
\text { TGAATGGGAGAGGTGTTTGT }\end{array}$ & 126 & 58 \\
\hline & $\begin{array}{l}\text { Bisulfite } \\
\text { sequencing }\end{array}$ & $\begin{array}{l}\text { Forward } \\
\text { Reverse }\end{array}$ & $\begin{array}{l}\text { TATTGGGAGGGAGTTTGGGA } \\
\text { TAC TCC CCA CCC TCA AAC TA }\end{array}$ & 411 & 66 \\
\hline$E Z R$ & qRT-PCR & $\begin{array}{l}\text { Forward } \\
\text { Reverse }\end{array}$ & $\begin{array}{l}\text { GATAGTCGTGTTTTCGGGGA } \\
\text { CTCTGCATCCATGGTGGTAA }\end{array}$ & 91 & 60 \\
\hline$F A K$ & qRT-PCR & $\begin{array}{l}\text { Forward } \\
\text { Reverse }\end{array}$ & $\begin{array}{l}\text { GCCAAAAGGATTTCTAAACCAG } \\
\text { CCTGGTCCACTTGATCAGCTA }\end{array}$ & 110 & 64 \\
\hline$S R C$ & qRT-PCR & $\begin{array}{l}\text { Forward } \\
\text { Reverse }\end{array}$ & $\begin{array}{l}\text { CTGACCGCATGGACCGT } \\
\text { AAGCCAACCTGTCACTTGGTA }\end{array}$ & 107 & 58 \\
\hline DPYSL3 & qRT-PCR & $\begin{array}{l}\text { Forward } \\
\text { Reverse }\end{array}$ & $\begin{array}{l}\text { AGAAGAAGGAGGGAGGGAGC } \\
\text { СТCССTTGATAAGGAGACGG }\end{array}$ & 110 & 60 \\
\hline GAPDH & qRT-PCR & $\begin{array}{l}\text { Forward } \\
\text { Probe } \\
\text { Reverse }\end{array}$ & $\begin{array}{l}\text { GAAGGTGAAGGTCGGAGTC } \\
\text { CAAGCTTCCCGTTCTCAGCC } \\
\text { GAAGATGGTGATGGGATTTC }\end{array}$ & 226 & 60 \\
\hline
\end{tabular}

$K A L 1$, Kallmann syndrome 1 sequence; $E Z R$, ezrin; FAK, focal adhesion kinase; SRC, cellular SRC; DPYSL3, Dihydropyrimidinase-like 3; $G A P D H$, glyceraldehyde-3-phosphate dehydrogenase; $q R T-P C R$, quantitative real-time reverse-transcription polymerase chain reaction; $M S P$, methylation specific PCR; $U$-MSP, un-methylation specific PCR.
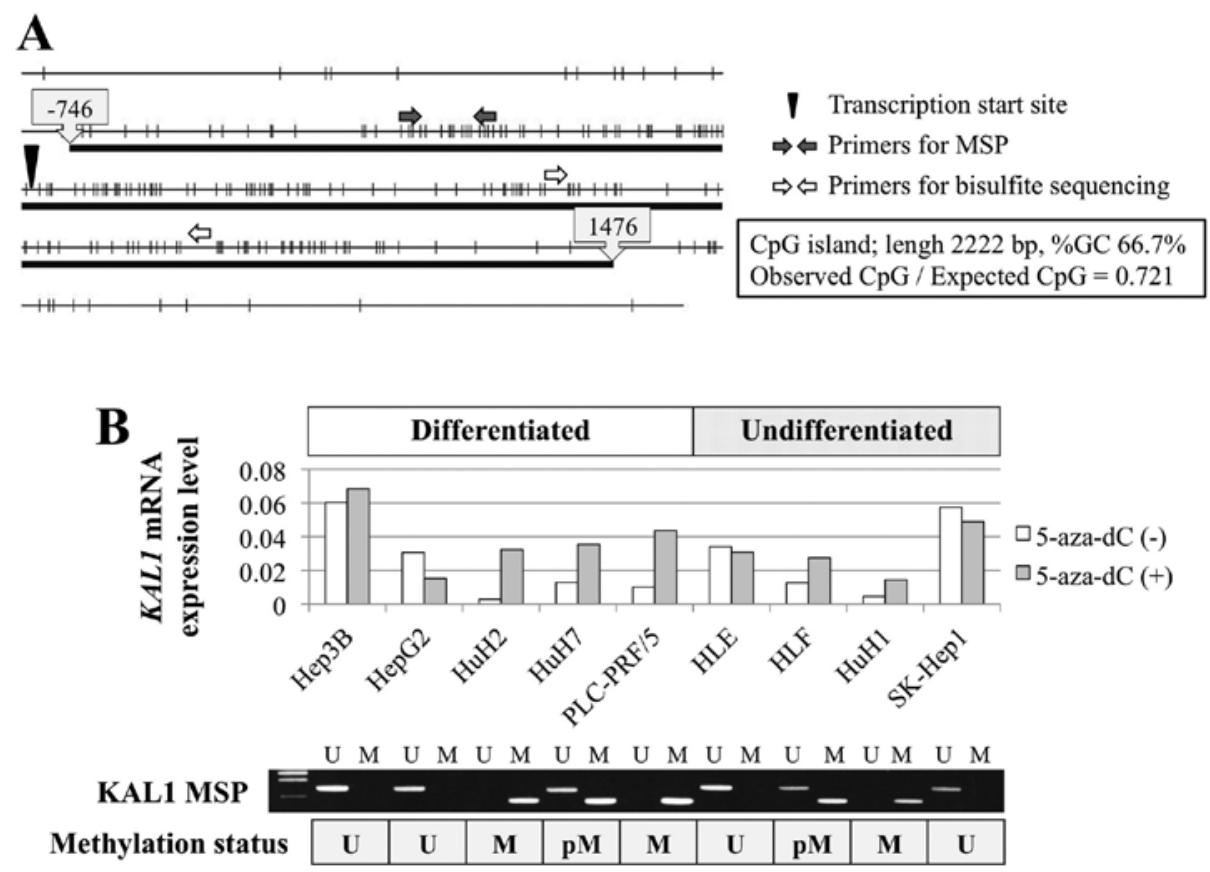

Figure 1. (A) The CpG island (indicated by the underline) is centered on the KAL1 transcription initiation site extending upstream into the promoter region. (B) Top: Bar graphs showing KAL1 mRNA expression levels in nine HCC cell lines before and after 5-aza-dC treatment. Bottom: The methylation status of KAL1 in the nine cell lines was determined by MSP. M, methylated; pM, partially methylated; U, unmethylated.

FAK, SRC, or DPYSL3 as well as tumor size and preoperative serum protein induced by vitamin $\mathrm{K}$ antagonists II (PIVKA-II) level were analyzed using the Spearman rank correlation test.

Overall and disease-free survival rates were calculated using 

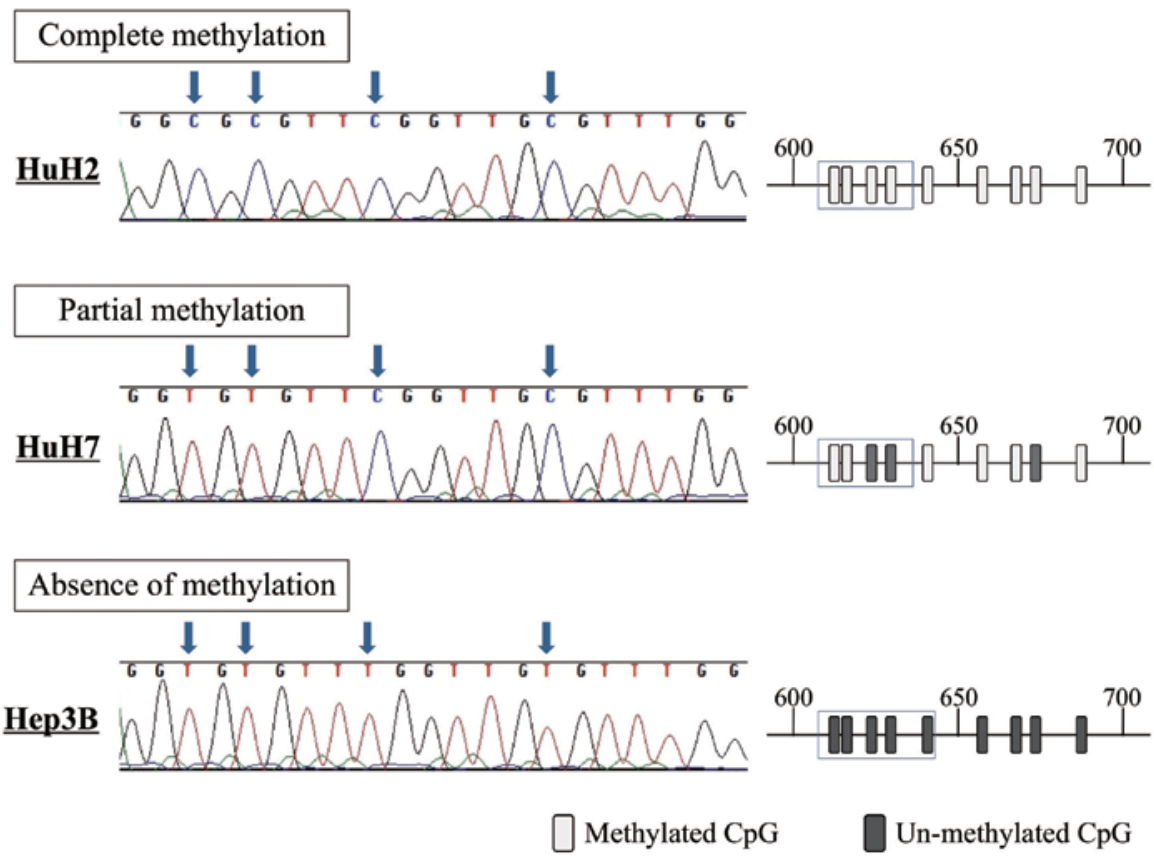

Figure 2. Representative results of bisulfite sequencing analysis. All CpG sites in $\mathrm{HuH} 2$ cell were retained as CG, while those of Hep3B were converted to TG. In $\mathrm{HuH} 7$, that was identified as a partially methylated cell by MSP, both CG and TG are shown.

the Kaplan-Meier method, and the difference in survival curves was evaluated using the log rank test. A P-value $<0.05$ was considered statistically significant. All statistical analysis was performed using JMP $10^{\circledR}$ software (SAS Institute Inc., Cary, NC, USA).

\section{Results}

KAL1 mRNA expression and methylation status in HCC cell lines. The KAL1 gene harbors a $\mathrm{CpG}$ island around the promoter region (Fig. 1A), suggesting that hypermethylation of the $\mathrm{CpG}$ island may regulate KAL1 transcription. KAL1 mRNA expression levels were heterogeneous among nine HCC cell lines, regardless of differentiation (Fig. 1B). MSP revealed methylation in $\mathrm{HLF}, \mathrm{HuH} 1, \mathrm{HuH} 2, \mathrm{HuH} 7$ and $\mathrm{PLC} /$ $\mathrm{PRF} / 5$ cells. When comparing the levels of KAL1 mRNA in HCC cell lines before and after demethylation by 5 -aza-dC treatment, reactivation of KAL1 mRNA expression was observed in cells with promoter hypermethylation of the KAL1 gene (Fig. 1B). Direct sequence analysis revealed that all $\mathrm{CpG}$ sites in $\mathrm{HuH} 2$ cells (complete methylation) were $\mathrm{CG}$ (cytosine and guanine), whereas the corresponding positions in Hep3B cells (absence of methylation) were TG (thymine and guanine) (Fig. 2). These results confirm the accuracy of the MSP results.

Expression analysis of KALI and genes encoding putative functional partners in HCC cell lines. We next evaluated the expression levels of genes encoding other cell adhesion factors that could potentially functionally interact with KAL1. The relative expression levels of EZR, FAK, SRC, DPYSL3, and KAL1 mRNAs in HCC cell lines are shown in Fig. 3A. The results showed that KAL1 mRNA levels inversely correlated with those of EZR (correlation coefficient -0.667, $\mathrm{P}=0.049$; Fig. 3B).
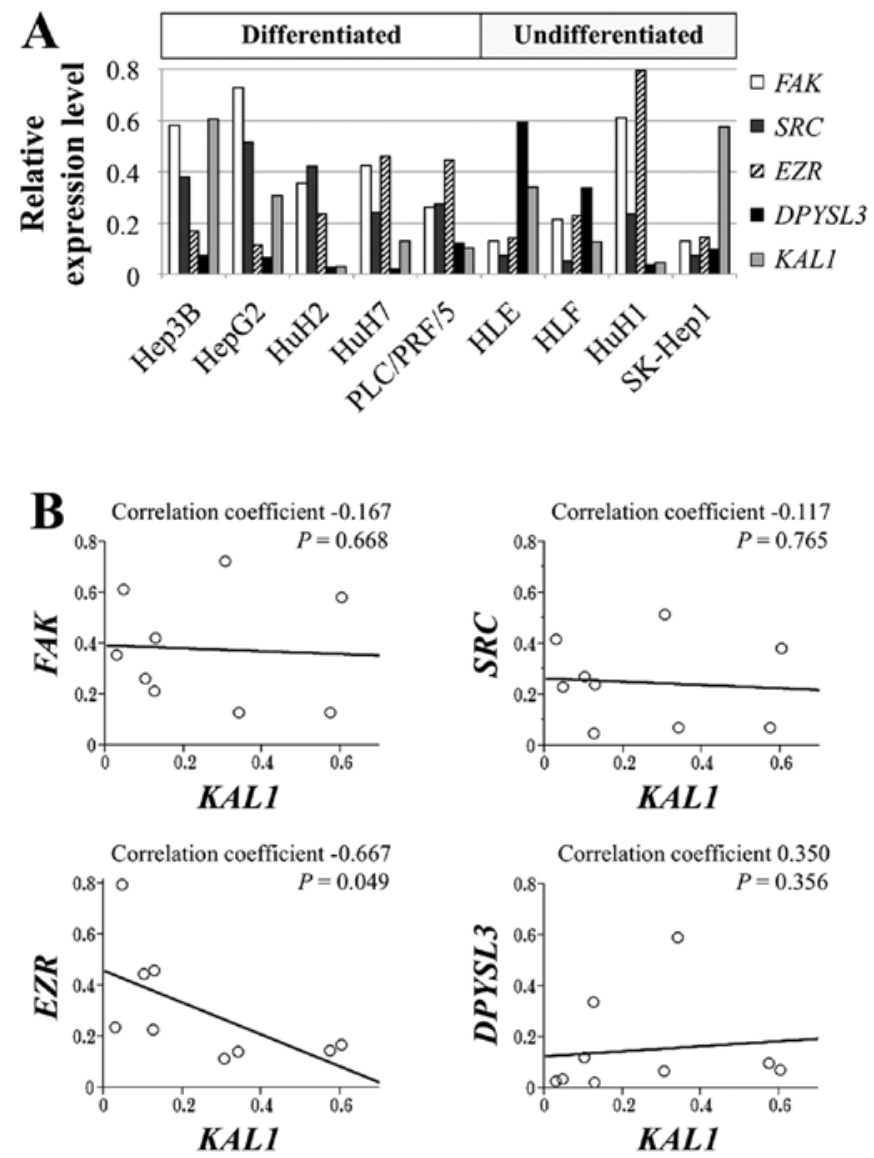

Figure 3. (A) Expression analysis of KAL1, FAK, SRC, EZR and DPYSL3 mRNA levels in nine HCC cell lines. (B) Correlations of mRNA expression levels between KAL1 and the four genes.

KAL1 status in surgically-resected tissues. We next examined KAL1 mRNA levels in 144 HCC tissues compared with the 
Table II. Association between expression levels of KAL1 mRNA and clinicopathological parameters in 144 patients with hepatocellular carcinoma (HCC).

\begin{tabular}{llll}
\hline & $\begin{array}{l}\text { Downregulation } \\
\text { Clinicopathological } K A L 1 \text { mRNA }\end{array}$ & $\begin{array}{l}\text { Others } \\
\text { of }\end{array}$ & P-value \\
parameters & in HCCs $(\mathrm{n}=62)$ & $(\mathrm{n}=82)$ & \\
\hline
\end{tabular}

Age
$<65$ year
$\geq 65$ year
Gender
Male
Female
Background liver
Normal liver
Chronic hepatitis
Cirrhosis

Pugh-Child's

classification

$$
\begin{aligned}
& \text { A } \\
& \text { B }
\end{aligned}
$$

Hepatitis virus

Absent
HBV
HCV

$\mathrm{AFP}(\mathrm{ng} / \mathrm{ml})$

$$
\leq 20
$$$$
>20
$$

PIVKA II (mAU/ml)

$$
\leq 40
$$

Tumor multiplicity

$$
\begin{aligned}
& \text { Solitary } \\
& \text { Multiple }
\end{aligned}
$$

Tumor size

$$
\begin{aligned}
& <3.0 \mathrm{~cm} \\
& \geq 3.0 \mathrm{~cm}
\end{aligned}
$$

Differentiation

$$
\text { Well }
$$

Moderate to poor

Growth type

Expansive growth

Invasive growth

Serosal infiltration

Absent

Present

Formation of capsule

$$
\text { Absent }
$$

Present

Infiltration to capsule
0.312

40

42

$0.004^{\mathrm{a}}$
Table II. Continued.

\begin{tabular}{lccc}
\hline $\begin{array}{l}\text { Clinicopathological } \\
\text { parameters }\end{array}$ & $\begin{array}{l}\text { Downregulation } \\
\text { of } K A L 1 \text { mRNA } \\
\text { in HCCs }(\mathrm{n}=62)\end{array}$ & $\begin{array}{l}\text { Others } \\
(\mathrm{n}=82)\end{array}$ & P-value \\
\hline $\begin{array}{l}\text { Septum formation } \\
\text { Absent }\end{array}$ & 19 & 31 & 0.370 \\
Present & 43 & 51 & \\
Vascular invasion & & & $0.033^{\mathrm{a}}$ \\
Absent & 41 & 67 & \\
Present & 21 & 15 & \\
Hypermethylation & & & $0.019^{\mathrm{a}}$ \\
of KAL1 in HCCs & & 58 & \\
Absent & 32 & 24 & \\
Present & 30 & & 0.062 \\
UICC pathological & & 57 & \\
stage & & 15 & \\
I & 33 & 10 & \\
II & 22 & & \\
III & 7 & & \\
\hline
\end{tabular}

$H B V$, hepatitis B virus; $H C V$, hepatitis $\mathrm{C}$ virus; $A F P, \alpha$-fetoprotein; $P I V K A$, protein induced by vitamin $\mathrm{K}$ antagonists; UICC, Union for International Cancer Control. ${ }^{\mathrm{a}} \mathrm{P}<0.05$, statistically significant difference.

corresponding noncancerous liver tissues. Results showed that KAL1 mRNA levels were lower in HCC tissues compared with the corresponding noncancerous liver tissues in 106 (74\%) of 144 patients. We next evaluated the association between expression levels of KAL1 mRNA and protein. Results of IHC, qPCR and MSP in representative patients are shown in Fig. 4A and B. One patient with reduced KAL1 mRNA levels showed reduced expression of KAL1 protein in the cytoplasm of HCC cells accompanied with promoter hypermethylation (Fig. 4A).

$0.004^{\mathrm{a}} \quad$ Equivalent expression of KAL1 in cancer and normal cells was detected in a patient without downregulation of KAL1 mRNA and methylation (Fig. 4B). The expression patterns of KAL1 in 64 patients correlated significantly with those of KAL1 mRNA ( $\mathrm{P}=0.023$, Fig. 4C).

There were no significant differences in KAL1 mRNA levels between normal liver, chronic hepatitis, and cirrhosis in noncancerous liver tissues. In contrast, HCC tissues showed significantly decreased KAL1 mRNA levels compared with the corresponding noncancerous liver tissues (Fig. 5A). The KAL1 mRNA levels in HCCs correlated inversely with tumor size and preoperative serum PIVKA-II level (Fig. 5B). In 62 patients, KAL1 mRNA expression level in HCC was less than half of that in the corresponding noncancerous liver tissue, and these patients were categorized into the 'downregulation of KAL1' group for the following analyses. Downregulation of KAL1 was significantly associated with $\alpha$-fetoprotein $>20 \mathrm{ng} / \mathrm{ml}$, PIVKA-II $>40 \mathrm{mAU} / \mathrm{ml}$, tumor size $\geq 3.0 \mathrm{~cm}$, moderate to poor differentiation, formation of a capsule, vascular invasion, and hypermethylation of KAL1 (Table II). 
A

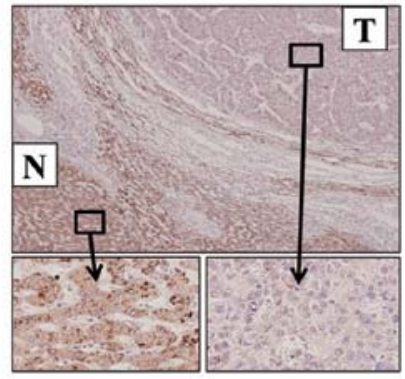

\section{qPCR}

$K A L 1$ mRNA;

$\mathrm{HCC} /$ non-cancerous $=0.192$

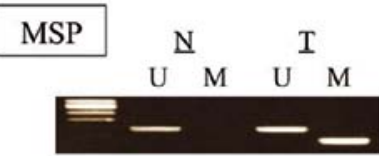

B

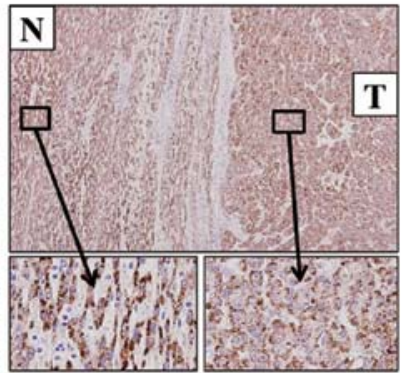

T

\section{KAL1 mRNA;}

$\mathrm{HCC} /$ non-cancerous $=1.181$

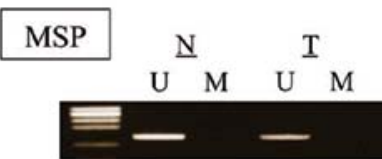

Figure 4. IHC, $q$ PCR and MSP results of representative patients with reduced (A) and equivalent (B) expression of KAL1 mRNA in HCCs compared with the corresponding noncancerous tissues. (C) The pattern of KAL1 protein expression significantly correlated with that of KAL1 mRNA in HCC tissues.

Impact of KAL1 mRNA expression on patient outcome. Patients with downregulation of KAL1 were more likely to have a shorter overall survival than other patients (5-year survival rates $51 \%$ and $78 \%$, respectively, $\mathrm{P}=0.002$ ) (Fig. 6A). In multivariate analysis, downregulation of KAL1 was identified as an independent prognostic factor (hazard ratio 2.04, 95\% confidence interval 1.11-3.90, $\mathrm{P}=0.022$; Table III). Additionally, patients with downregulation of KAL1 tended to have a shorter disease-free survival compared with other patients, although it did not reach statistical significance (3-year survival rates $32 \%$ and $50 \%$, respectively, $\mathrm{P}=0.014$ ) (Fig. 6B).

\section{Discussion}

Impaired expression of genes encoding ECM proteins plays an important role in the initiation and progression of $\operatorname{HCC}(16,32)$. KAL1, one of the ECM-related proteins, has been reported to have diverse oncological functions $(15,17)$. In the present study, the clinical significance of the expression and methylation status of KAL1 was evaluated in HCC.

Consistent with earlier studies in colon, lung and breast cancer (17), our results showed that expression levels of KAL1 were reduced in HCC tissues compared to adjacent noncancerous liver tissues. Furthermore, KAL1 expression was independent of chronic inflammation or fibrosis of the background liver, suggesting that downregulation of KAL1 is a specific event in hepatocarcinogenesis or at later stages. Loss-of-function mutations in the KAL1 gene are responsible for Kallmann syndrome, a developmental disorder characterized by the association of hypogonadotropic hypogonadism and anosmia $(14,18,19)$. However, no studies have investigated the regulatory mechanisms of KAL1 expression in malignancies. Since a $\mathrm{CpG}$ island was found in the promoter region of the KAL1 gene, we focused on aberrant DNA methylation, which is an important mechanism for inactivation of tumor suppressors $(33,34)$. Our results showed that HCC cell lines with profoundly suppressed KAL1 expression also harbored promoter hypermethylation of the KAL1 gene, and expression levels of KAL1 were restored by demethylation. Additionally, there was a significant association between downregulation of KAL1 mRNA and hypermethylation of KAL1 gene in surgically resected HCC tissues. These findings implicated that aberrant methylation is a pivotal regulatory mechanism for KAL1 expression in HCC. Promoter hypermethylation of the KAL1 gene has the potential for becoming a novel biomarker of HCC as well as a therapeutic target for specific demethylation agents $(34,35)$.

We also investigated the levels of other important ECM-related proteins, and found that the expression level of KAL1 had a significant inverse association with EZR expression. EZR is a cytoplasmic peripheral membrane protein that functions as a substrate of protein tyrosine kinases, regulates cellular survival, adhesion, migration, and invasion. Importantly, EZR is also one of the key factors involved in tumor progression and metastasis in HCC (36-39). Our finding supports the notion that KAL1 may function through tumor suppressor mechanisms and led us to speculate that KAL1 may interact with EZR and mediate tumorigenesis of HCC.

The significant correlation between the IHC and qRT-PCR data allowed us to evaluate the prognostic significance of KAL1 mRNA levels in a quantitative manner. Downregulation of KAL1 mRNA in HCC was significantly associated with factors reflecting the malignant potential of $\mathrm{HCC}$ and consequently deteriorated patient outcomes after curative hepatectomy. In contrast to the previous study showing that KAL1 overexpression promotes brain tumor malignancy (15), our results instead support a tumor suppressive role for KAL1 in HCC.

KAL1 was first identified through its function in the development of gonadotropin-releasing hormone neurons. Previous studies demonstrated that the expression of KAL1 is modulated by FGFR 1 and hypoxia inducible factor- $1 \alpha$ (HIF-1 $\alpha)(11,14)$. FGFR-1 expression was reported as low in normal liver epithelium and high in human liver cancer epithelium $(40,41)$. FGFR-1 protein may be important in regulating cytoskeletal dynamics and function in cancer cell invasion and metastatic behavior (42). HIF-1 $\alpha$ is an important transcription factor in essential adaptive responses to hypoxia, and plays a major role in the development of characteristic tumor phenotypes, including growth rate, angiogenesis, invasiveness, and metastasis, via activation of target genes by binding to hypoxia-responsive elements in the gene regulatory sequences (43-45). The interactions with these major oncogenic pathways might provide a 

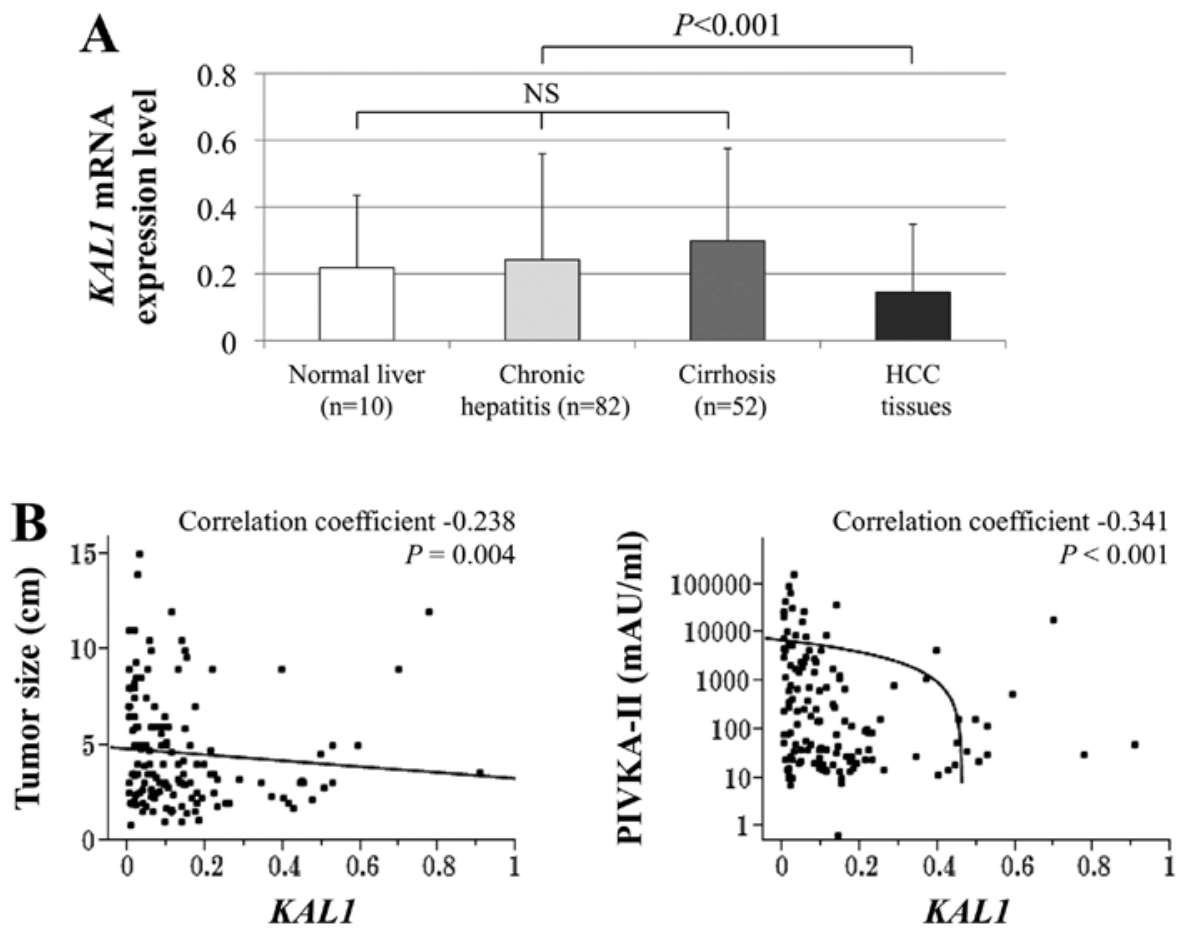

Figure 5. (A) Comparison of KAL1 mRNA levels in normal, chronic hepatitis, cirrhotic, and HCC tissues. (B) Expression levels of KAL1 mRNA were significantly correlated with tumor size and preoperative PIVKA-II levels.

Table III. Prognostic factors of 144 patients with hepatocellular carcinoma (HCC) for overall survival.

\begin{tabular}{|c|c|c|c|c|c|c|c|}
\hline \multirow[b]{2}{*}{ Variable } & \multirow[b]{2}{*}{$\mathrm{n}$} & \multicolumn{3}{|c|}{ Univariate } & \multicolumn{3}{|c|}{ Multivariate } \\
\hline & & Hazard ratio & $95 \% \mathrm{CI}$ & P-value & Hazard ratio & $95 \% \mathrm{CI}$ & P-value \\
\hline Age $(\geq 65)$ & 79 & 1.75 & $0.96-3.30$ & 0.068 & & & \\
\hline Gender (male) & 121 & 1.82 & $0.78-5.29$ & 0.178 & & & \\
\hline Background liver (cirrhosis) & 52 & 1.53 & $0.84-2.75$ & 0.161 & & & \\
\hline Pugh-Child's classification (B) & 10 & 1.68 & $0.50-4.19$ & 0.360 & & & \\
\hline $\operatorname{AFP}(>20 \mathrm{ng} / \mathrm{ml})$ & 66 & 1.96 & $1.09-3.58$ & $0.024^{\mathrm{a}}$ & 1.49 & $0.81-2.78$ & 0.196 \\
\hline PIVKA II (>40 mAU/ml) & 86 & 1.90 & $1.03-3.71$ & $0.041^{\mathrm{a}}$ & 1.04 & $0.50-2.06$ & 0.909 \\
\hline Tumor multiplicity (multiple) & 32 & 1.83 & $0.94-3.38$ & 0.073 & & & \\
\hline Tumor size ( $\geq 3.0 \mathrm{~cm})$ & 98 & 2.84 & $1.38-6.64$ & $0.004^{\mathrm{a}}$ & 1.95 & $0.88-4.86$ & 0.103 \\
\hline Tumor differentiation (well) & 35 & 0.72 & $0.34-1.41$ & 0.349 & & & \\
\hline Growth type (invasive growth) & 24 & 1.71 & $0.84-3.26$ & 0.136 & & & \\
\hline Serosal infiltration & 35 & 2.23 & $1.16-4.11$ & $0.017^{\mathrm{a}}$ & 1.70 & $0.87-3.18$ & 0.115 \\
\hline Formation of capsule & 97 & 0.95 & $0.52-1.81$ & 0.861 & & & \\
\hline Infiltration to capsule & 78 & 1.24 & $0.69-2.29$ & 0.478 & & & \\
\hline Septum formation & 94 & 0.77 & $0.43-1.43$ & 0.402 & & & \\
\hline Vascular invasion & 36 & 3.75 & $2.05-6.78$ & $<0.001^{\mathrm{a}}$ & 2.48 & $1.30-4.71$ & $0.006^{\mathrm{a}}$ \\
\hline Hypermethylation of KAL1 in HCCs & 54 & 1.23 & $0.67-2.33$ & 0.511 & & & \\
\hline Downregulation of $K A L 1$ mRNA & 62 & 2.53 & $1.40-4.73$ & $0.002^{\mathrm{a}}$ & 2.04 & $1.11-3.90$ & $0.022^{\mathrm{a}}$ \\
\hline
\end{tabular}

$C I$, confidence interval; $A F P$, a-fetoprotein; PIVKA, protein induced by vitamin $\mathrm{K}$ antagonists. Univariate analysis was performed using the log-rank test. Multivariate analysis was performed using the Cox proportional hazards model. ${ }^{a} \mathrm{P}<0.05$, statistically significant.

mechanism(s) underlying the correlation between KAL1 expression and malignant phenotype of HCC. Future studies, including pathway analysis in hepatocarcinogenesis, hypoxic stress and functional analysis, are required to elucidate the molecular mechanisms that underlie the biological function of KAL1 in HCC. 

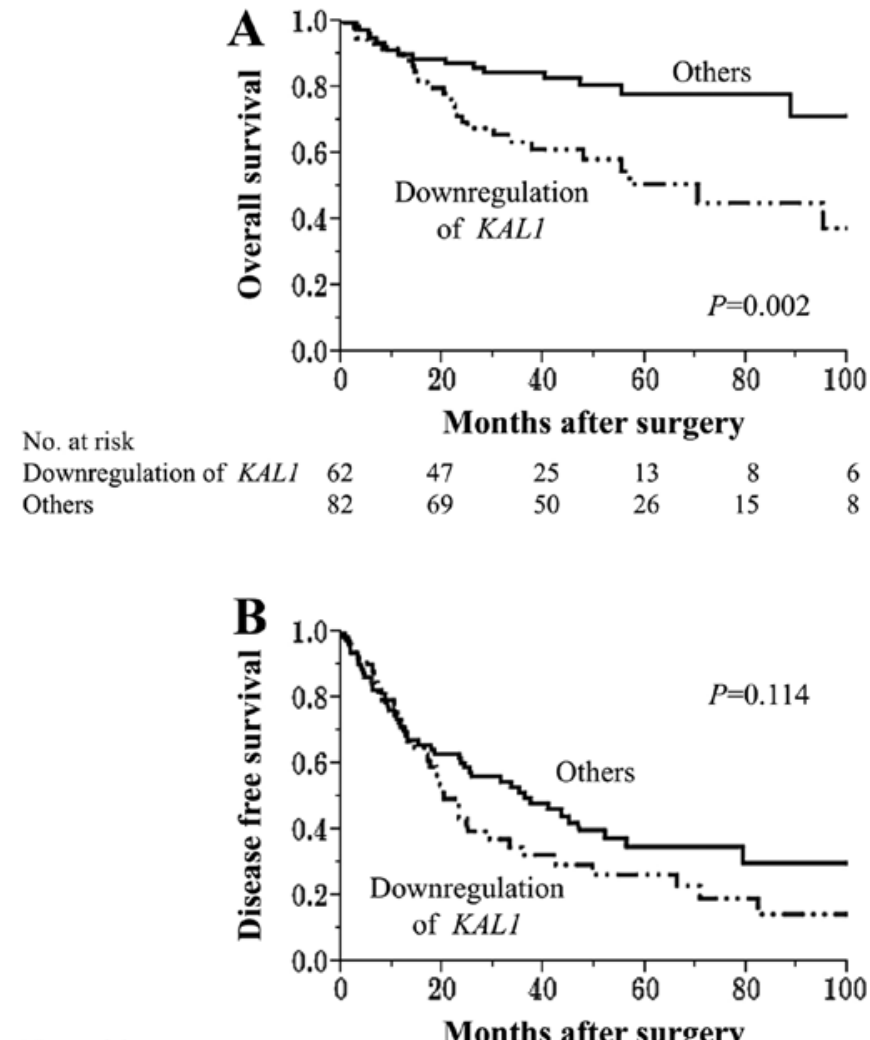

No. at risk

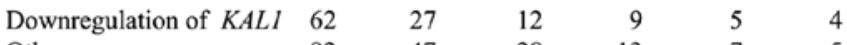

$\begin{array}{lllllll}\text { Others } & 82 & 47 & 28 & 13 & 7 & 5\end{array}$

Figure 6. Prognostic impact of downregulation of KAL1. (A) Patients with downregulation of KAL1 mRNA experienced significantly shorter overall survival compared with other patients. (B) Disease-free survival tended to be shorter in patients with downregulation of KAL1 mRNA compared with other patients.

Taken together, our results indicate that KAL1 acts as a putative tumor suppressor in HCC that is inactivated by promoter hypermethylation. Our findings suggest that KAL1 may serve as a promising biomarker of malignant phenotype of HCC.

\section{References}

1. Siegel R, Ward E, Brawley O and Jemal A: Cancer statistics, 2011: The impact of eliminating socioeconomic and racial disparities on premature cancer deaths. CA Cancer J Clin 61: 212-236, 2011.

2. Galuppo R, Ramaiah D, Ponte OM and Gedaly R: Molecular therapies in hepatocellular carcinoma: What can we target? Dig Dis Sci 59: 1688-1697, 2014.

3. Giannelli G, Rani B, Dituri F, Cao Y and Palasciano G: Moving towards personalised therapy in patients with hepatocellular carcinoma: The role of the microenvironment. Gut 63: 1668-1676, 2014.

4. Kanda M, Nomoto S, Nishikawa Y, Sugimoto H, Kanazumi N, Takeda S and Nakao A: Correlations of the expression of vascular endothelial growth factor B and its isoforms in hepatocellular carcinoma with clinico-pathological parameters. J Surg Oncol 98: 190-196, 2008.

5. El-Serag HB: Hepatocellular carcinoma. N Engl J Med 365: 1118-1127, 2011.

6. Sawan C, Vaissière T, Murr R and Herceg Z: Epigenetic drivers and genetic passengers on the road to cancer. Mutat Res 642 : $1-13,2008$.

7. Kanda M, Sugimoto H, Nomoto S, Oya H, Hibino S, Shimizu D, Takami H, Hashimoto R, Okamura Y, Yamada S, et al: B-cell translocation gene 1 serves as a novel prognostic indicator of hepatocellular carcinoma. Int J Oncol 46: 641-648, 2015.
8. Hernandez-Gea V, Toffanin S, Friedman SL and Llovet JM: Role of the microenvironment in the pathogenesis and treatment of hepatocellular carcinoma. Gastroenterology 144: 512-527, 2013.

9. Arzumanyan A, Reis HM and Feitelson MA: Pathogenic mechanisms in HBV- and HCV-associated hepatocellular carcinoma. Nat Rev Cancer 13: 123-135, 2013.

10. Kanda M, Sugimoto H, Nomoto S, Oya H, Shimizu D, Takami H, Hashimoto R, Sonohara F, Okamura Y, Yamada S, et al: Clinical utility of PDSS2 expression to stratify patients at risk for recurrence of hepatocellular carcinoma. Int J Oncol 45: 2005-2012, 2014

11. Soussi-Yanicostas N, de Castro F, Julliard AK, Perfettini I, Chédotal A and Petit C: Anosmin-1, defective in the X-linked form of Kallmann syndrome, promotes axonal branch formation from olfactory bulb output neurons. Cell 109: 217-228, 2002.

12. Di Schiavi E and Andrenacci D: Invertebrate models of kallmann syndrome: Molecular pathogenesis and new disease genes. Curr Genomics 14: 2-10, 2013.

13. Liu J, Cao W, Chen W, Xu L and Zhang C: Decreased expression of Kallmann syndrome 1 sequence gene (KAL1) contributes to oral squamous cell carcinoma progression and significantly correlates with poorly differentiated grade. J Oral Pathol Med 44: 109-114, 2015.

14. González-Martínez D, Kim SH, Hu Y, Guimond S, Schofield J, Winyard P, Vannelli GB, Turnbull J and Bouloux PM: Anosmin-1 modulates fibroblast growth factor receptor 1 signaling in human gonadotropin-releasing hormone olfactory neuroblasts through a heparan sulfate-dependent mechanism. J Neurosci 24: 10384-10392, 2004.

15. Choy CT, Kim H, Lee JY, Williams DM, Palethorpe D, Fellows G, Wright AJ, Laing K, Bridges LR, Howe FA, et al: Anosmin-1 contributes to brain tumor malignancy through integrin signal pathways. Endocr Relat Cancer 21: 85-99, 2014.

16. Kanda M, Nomoto S, Okamura Y, Hayashi M, Hishida M, Fujii T, Nishikawa Y, Sugimoto H, Takeda $S$ and Nakao A: Promoter hypermethylation of fibulin 1 gene is associated with tumor progression in hepatocellular carcinoma. Mol Carcinog 50: 571-579, 2011.

17. Jian B, Nagineni CN, Meleth S, Grizzle W, Bland K, Chaudry I and Raju R: Anosmin-1 involved in neuronal cell migration is hypoxia inducible and cancer regulated. Cell Cycle 8: 3770-3776, 2009.

18. Guioli S, Incerti B, Zanaria E, Bardoni B, Franco B, Taylor K, Ballabio A and Camerino G: Kallmann syndrome due to a translocation resulting in an X/Y fusion gene. Nat Genet 1: 337-340, 1992.

19. Hardelin JP, Levilliers J, del Castillo I, Cohen-Salmon M, Legouis R, Blanchard S, Compain S, Bouloux P, Kirk J, Moraine C, et al: X chromosome-linked Kallmann syndrome: Stop mutations validate the candidate gene. Proc Natl Acad Sci USA 89: 8190-8194, 1992.

20. Nomoto S, Kanda M, Okamura Y, Nishikawa Y, Qiyong L, Fujii T, Sugimoto H, Takeda $S$ and Nakao A: Epidermal growth factor-containing fibulin-like extracellular matrix protein 1 , EFEMP1, a novel tumor-suppressor gene detected in hepatocellular carcinoma using double combination array analysis. Ann Surg Oncol 17: 923-932, 2010.

21. Kanda M, Nomoto S, Oya H, Takami H, Hibino S, Hishida M, Suenaga M, Yamada S, Inokawa Y, Nishikawa Y, et al: Downregulation of DENND2D by promoter hypermethylation is associated with early recurrence of hepatocellular carcinoma. Int J Oncol 44: 44-52, 2014.

22. Shimizu D, Kanda M, Nomoto S, Oya H, Takami H, Hibino S, Suenaga M, Inokawa Y, Hishida M, Takano N, et al: Identification of intragenic methylation in the TUSC1 gene as a novel prognostic marker of hepatocellular carcinoma. Oncol Rep 31: 1305-1313, 2014.

23. Takami H, Kanda M, Oya H, Hibino S, Sugimoto H, Suenaga M, Yamada S, Nishikawa Y, Asai M, Fujii T, et al: Evaluation of MAGE-D4 expression in hepatocellular carcinoma in Japanese patients. J Surg Oncol 108: 557-562, 2013.

24. Sobin LH, Gospodarowicz MK and Wittekind C (eds): International Union Against Cancer, TNM Classification of Malignant Tumors. 7th edition. Wiley-Blackwell, New York, 2009.

25. Kanda M, Nomoto S, Oya H, Hashimoto R, Takami H, Shimizu D, Sonohara F, Kobayashi D, Tanaka C, Yamada S, et al: Decreased expression of prenyl diphosphate synthase subunit 2 correlates with reduced survival of patients with gastric cancer. J Exp Clin Cancer Res 33: 88, 2014. 
26. Takai D and Jones PA: The CpG island searcher: A new WWW resource. In Silico Biol 3: 235-240, 2003.

27. Kanda M, Nomoto S, Oya H, Shimizu D, Takami H, Hibino S, Hashimoto R, Kobayashi D, Tanaka C, Yamada S, et al: Dihydropyrimidinase-like 3 facilitates malignant behavior of gastric cancer. J Exp Clin Cancer Res 33: 66, 2014.

28. Kanda M, Shimizu D, Nomoto S, Hibino S, Oya H, Takami H, Kobayashi D, Yamada S, Inokawa Y, Tanaka C, et al: Clinical significance of expression and epigenetic profiling of TUSC1 in gastric cancer. J Surg Oncol 110: 136-144, 2014.

29. Kawahara T, Hotta N, Ozawa Y, Kato S, Kano K, Yokoyama Y, Nagino M, Takahashi T and Yanagisawa K: Quantitative proteomic profiling identifies DPYSL3 as pancreatic ducta adenocarcinoma-associated molecule that regulates cell adhesion and migration by stabilization of focal adhesion complex. PLoS One 8: e79654, 2013.

30. Oya H, Kanda M, Sugimoto H, Shimizu D, Takami H, Hibino S, Hashimoto R, Okamura Y, Yamada S, Fujii T, et al: Dihydropyrimidinase-like 3 is a putative hepatocellular carcinoma tumor suppressor. J Gastroenterol: Aug 31, 2014 (Epub ahead of print).

31. Kanda M, Shimizu D, Nomoto S, Takami H, Hibino S, Oya H, Hashimoto R, Suenaga M, Inokawa Y, Kobayashi D, et al: Prognostic impact of expression and methylation status of DENN/ MADD domain-containing protein 2D in gastric cancer. Gastric Cancer 18: 288-296, 2015.

32. Yam JW, Tse EY and Ng IO: Role and significance of focal adhesion proteins in hepatocellular carcinoma. J Gastroenterol Hepatol 24: 520-530, 2009.

33. Maunakea AK, Nagarajan RP, Bilenky M, Ballinger TJ, D'Souza C, Fouse SD, Johnson BE, Hong C, Nielsen C, Zhao Y, et al: Conserved role of intragenic DNA methylation in regulating alternative promoters. Nature 466: 253-257, 2010.

34. Khare S, Zhang Q and Ibdah JA: Epigenetics of hepatocellular carcinoma: Role of microRNA. World J Gastroenterol 19 5439-5445, 2013.

35. Miki D, Ochi H, Hayes CN, Aikata H and Chayama K: Hepatocellular carcinoma: Towards personalized medicine. Cancer Sci 103: 846-850, 2012

36. Kang YK, Hong SW, Lee H and Kim WH: Prognostic implications of ezrin expression in human hepatocellular carcinoma. Mol Carcinog 49: 798-804, 2010.
37. Chen Y, Wang D, Guo Z, Zhao J, Wu B, Deng H, Zhou T, Xiang H, Gao F, Yu X, et al: Rho kinase phosphorylation promotes ezrinmediated metastasis in hepatocellular carcinoma. Cancer Res 71: 1721-1729, 2011.

38. Ghaffari A, Hoskin V, Szeto A, Hum M, Liaghati N, Nakatsu K, Madarnas Y, Sengupta S and Elliott BE: A novel role for ezrin in breast cancer angio/lymphangiogenesis. Breast Cancer Res 16: 438,2014

39. Piao J, Liu S, Xu Y, Wang C, Lin Z, Qin Y and Liu S: Ezrin protein overexpression predicts the poor prognosis of pancreatic ductal adenocarcinomas. Exp Mol Pathol 98: 1-6, 2014.

40. Ogasawara S, Yano H, Iemura A, Hisaka T and Kojiro M: Expressions of basic fibroblast growth factor and its receptors and their relationship to proliferation of human hepatocellular carcinoma cell lines. Hepatology 24: 198-205, 1996.

41. Huang X, Yu C, Jin C, Kobayashi M, Bowles CA, Wang F and McKeehan WL: Ectopic activity of fibroblast growth factor receptor 1 in hepatocytes accelerates hepatocarcinogenesis by driving proliferation and vascular endothelial growth factorinduced angiogenesis. Cancer Res 66: 1481-1490, 2006.

42. Wang J, Li J, Wang X, Zheng C and Ma W: Downregulation of microRNA-214 and overexpression of FGFR-1 contribute to hepatocellular carcinoma metastasis. Biochem Biophys Res Commun 439: 47-53, 2013.

43. Zheng SS, Chen XH, Yin X and Zhang BH: Prognostic significance of HIF-1 $\alpha$ expression in hepatocellular carcinoma: A meta-analysis. PLoS One 8: e65753, 2013.

44. Wu L, Fu Z, Zhou S, Gong J, Liu CA, Qiao Z and Li S: HIF-1a and HIF-2 $\alpha$ : Siblings in promoting angiogenesis of residual hepatocellular carcinoma after high-intensity focused ultrasound ablation. PLoS One 9: e88913, 2014.

45. Yamada S, Utsunomiya T, Morine Y, Imura S, Ikemoto T, Arakawa Y, Kanamoto M, Iwahashi S, Saito Y, Takasu C, et al: Expressions of hypoxia-inducible factor-1 and epithelial cell adhesion molecule are linked with aggressive local recurrence of hepatocellular carcinoma after radiofrequency ablation therapy. Ann Surg Oncol 21 (Suppl 3): S436-S442, 2014. 